courts to distinguish between the burden of proof and the burden of producing evidence. In some cases involving extra-hazardous activity, the courts, being reluctant openly to defy the fault rule of liability, have raised a presumption in the plaintiff's favor and required the defendant to sustain the burden of proof in the rebuttal..$^{23}$ Since it is frequently impossible for the defendant to extricate himself from this situation, the courts really inflict absolute liability. Thus, by a circuitous method the case is taken out of the field of evidence and into the substantive law of torts. Whatever may be the merits of such a shift, it is far better to meet the issue of absolute liability in the open than to complicate the already bewildering law of presumptions.

If courts realized that the phrase furnishes absolutely no criteria for determining negligence, they would make better use of the wisdom embodied in the general principles of evidence. Further, if no longer pinned down by precedent, they would be more apt to make the procedural step proper to the weight of the evidence advanced in each case. But there is undeniable merit in any attempt to relieve trial court judges from making new evaluations of recurring fact situations. If negligence cases could be catalogued into three classes corresponding to the three procedural steps with a different formula for each class an invaluable aid would be given trial judges. However, until such a classification is made, only confusion can attend the use of the phrase res ipsa loquitur.

\title{
THE RULE IN SHELLEY'S CASE AS APPLIED TO CONTINGENT REMAINDERS
}

In a recent Illinois case ${ }^{x}$ the facts were these: $G$ deeded land to $B$ and her husband ". . . . for and during their life time, then to the heirs of the body of our daughter, $\mathrm{B}$, and if she leaves no child or children surviving her, then to her heirs according to law." B died childless. The defendant, B's husband, to whom she devised all her real estate maintained that the above grant gave a joint estate for life to him and his wife, then a contingent remainder to her children which never vested because she died without children, and finally a contingent remainder to her heir at law, which by the Rule in Shelley's Case, was given to her as the ancestor. The court held that the rule did not apply to contingent remainders, and gave the estate to the heirs at law.

The Rule in Shelley's Case epitomizes the layman's conception of the technicality of law. When ordinary rules of construction have determined that the grantor intended an estate of freehold for the ancestor and a remainder to his

${ }^{23}$ Bohlen, Studies in the Law of Torts, c. XV (rg26), especially pp. 646,647. See also Carpenter, Doctrine of Res Ipsa Loquitur, r Univ. Chi. L. Rev. 519, 534 (I934). Prof. Bohlen suggests this as a method of attaining absolute liability because of the difficulty the defendant would have in sustaining disproof. Prof. Carpenter advocates this view for all cases because it would simplify trial procedure. Since Prof. Carpenter can hardly be advocating a return to absolute liability, he must be implicitly disagreeing with Prof. Bohlen as to the difficulty the defendant would have in meeting the burden of proof.

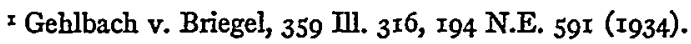


indefinite successors, the rule then operates automatically and inevitably to give the interest intended for the indefinite successors to the ancestor. ${ }^{2}$ Thus the rule defeats the intention of the grantor by substituting the ancestor, for whom no greater interest than the given estate was intended, for the indefinite successors as taker of the remainder. ${ }^{3}$

The original reasons for this six hundred year old rule ${ }^{4}$ no longer exist. ${ }^{5}$ Its application to modern cases is due to precedent. The court in the instant case, basing its decision on precedent, cited the following cases and writers as authority for the proposition that the rule does not apply to contingent remainders: ${ }^{6}$ Bails v. Davis, ${ }^{7}$ Westcott v. Meeker, ${ }^{8}$ Doyle v. Andis, ${ }^{9}$ Campbell v.

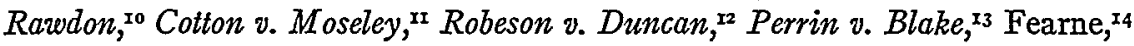
and Kent. ${ }^{x 5}$ Subsequently the court cites as "decisive of the present inquiry," Boon v. Boon, ${ }^{17}$ and denies Kales' contention that Hanes v. Central Illinois Utilities $\mathrm{Co}^{\mathrm{I}}{ }^{\mathrm{I}}$ upholds the application of the rule. ${ }^{\mathrm{I}}$. An examination of all these authorities reveals that they do not support the position of the court.

In Bails v. Davis" the grant was "to A and his wife, during their natural lives, and after their death to the heirs of A." The rule was applied. In Cotton v. Moseley ${ }^{2 x}$ the conveyance was similar except that the remainder was to the wife's heirs; again the rule was applied. The court in the principal case relied partly on the doctrine of merger as a condition precedent to application of the rule. ${ }^{22}$ Bails v. Davis contains a clear dictum that the Rule in Shelley's Case does not necessarily involve the doctrine of merger; in Cotton v. Moseley is a dictum that the rule does apply to contingent remainders.

2 I Hayes, Conveyancing 542 ( 5 th ed. I840).

3 Ibid., Hayes, at 543 .

4 Blackstone said that the first case he found, after a diligent search, was Abel's case in Maynard, I8 Edw. II. 577, 2 fol. (I324). See his opinion in Perrin v. Blake, 3 Hargrave, Jurisconsult Excercitations 393-395 ( $18 \mathrm{I}_{3}$ ), for a brief history of the rule.

$s$ Even at Blackstone's time only contradictory reasons for the rule could be suggested. Blackstone gave the following three reasons for the rule: first, the feudal reason of preserving the incidents of tenure for the lord which would be lost to him if the heir were permitted to take by purchase; second, to prevent the inheritance from being in abeyance; third, "to facilitate the alienation of the land and to throw it on the rack of commerce one generation sooner." This last reason, Blackstone says, is "diametrically opposed to the genius of feudal institutions." 3 Hargrave, Jurisconsult Excercitations 393, 395 (I8I3).

6 Gehlbach v. Briegel, 359 Ill. 3I6, 320, x94 N.E. 59r, 593 (1934).

724 I Tll. 536, 89 N.E. 706 (rgog).

${ }^{8}$ I 44 Ia. 3II, I 22 N.W. 964 (Ig09).

1274 N.J. Eq. 745, 70 Atl. 685 (Igo8).

9 I27 Ia. 36, I02 N.W. I77 (r905).

${ }^{2}$ I Hargrave, Law Tracts 503, 504 (I787).

Io I8 N.Y. 412 (1858).

Ix I $_{59}$ N.C. $x, 74$ S.E. 454 (IgI2).

${ } 4$ Fearne, Contingent Remainders 25.

${ }^{6} 6$ Gehlbach v. Briegel, 359 Tll. 316, 322, 323, I94 N.E. 59I, 593 (I935).

${ }^{17} 348$ Ill. ×20, I80 N.E. 792 (I932).

${ }^{20} 24 \mathrm{r}$ Ill. 536, 89 N.E. 706 (IgOg).

${ }^{18} 262$ Ill. 86, I04 N.E. I56 (I9r4).

${ }^{2 x}$ I 59 N.C. I, 74 S.E. 454 (rgI2).

x9 Kales, Future Interests 505 (I920).

${ }^{22}$ Infra note 33 . 
Doyle v. Andis ${ }^{23}$ established that the rule applies in Iowa to conveyances inter vivos. Campbell v. Rawdon ${ }^{24}$ did not involve the problem, since no freehold was given to the ancestor.

In Perrin v. Blake ${ }^{25}$ and Westcott v. Meeker ${ }^{26}$ the problem was whether an explicit statement that the ancestor was not to have the power of alienating more than a life estate prevented the application of the rule. In the former case it was held that the rule, not being one of construction, still applied; in the latter, the court denied application of the rule where the intent of the testator was clearly expressed.

There is a dictum in Robeson v. Duncan ${ }^{27}$ declaring that the rule does not apply to contingent remainders. However, the complete confusion of that court in interpreting the limitation ${ }^{28}$ somewhat weakens the authority of the case.

In Boon v. Boon 29 and Hanes v. Central Illinois Utilities Co., ${ }^{30}$ the limitations were similar to the one in the principal case: a life estate to the ancestor, a remainder to his children, and if he had no children surviving, a remainder to his heirs at law. In both cases the first remainder was regarded as having been limited to the definite successors, thus precluding the operation of the rule. In both cases, however, since there were children surviving, the second remainder was not in issue. And there is a dictum in the Hanes case, declaring that the rule would have applied to the second remainder, had it been in issue. ${ }^{32}$

Neither Fearne nor Kent denies the application of the rule to contingent remainders. In fact, Fearne, nine pages after the page cited by the court, explicitly states that the rule does apply. ${ }^{32}$

The court, then, has cited one text and two cases which are more properly authority for the opposite contention;33 one text and four cases which are authority for neither contention; ${ }^{34}$ and one case which because of the faulty reasoning involved is authority for its contention. ${ }^{35}$ Further, having discovered

$$
{ }^{23} \text { I27 Ia. 36, 102 N.W. I77 (I905). } \quad{ }_{24}^{4} \text { I8 N.Y. 4I2 (I858). }
$$

25 I Hargrave, Law Tracts 489,503 ( 1787 ). Even the dictum cited here might be damaging to the court's thesis since Blackstone lists only four exceptions to the rule and the instant case falls within none of these.

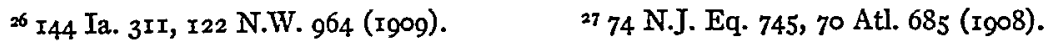

${ }_{28}$ The limitation was to $\mathrm{H}$ and the heirs of her body and a life estate reserved to the grantor with a condition attached that if $H$ died without heirs of her body, the estate was to revert to the grantor or his estate. But see Woodbridge v. Jarrard, Ior N.J. Eq. 439, 44I, I38 Atl. 536, 537 (1927).

${ }^{29} 348$ Ill. I 20, I 80 N.E. 792 (1932), $\quad 3^{30} 262$ Ill. 86 , I04 N.E. I 56 (1914).

${ }^{3 \mathrm{x}} 262 \mathrm{IIl} .86$, go, I04 N.E. I56, I57 (1914).

${ }^{32}$ Fearne, Contingent Remainders 30, 34 (roth ed. I844).

${ }_{33}$ Fearne, Contingent Remainders 30,34 (roth ed. I844); Bails v. Davis, 24I Ill. 536, 89 N.E. 706 (rgog); Cotton v. Moseley, 159 N.C. x, 74 S.E. 454 (rgI2).

${ }_{34} 4$ Kent, Commentaries 218 (1896); Doyle v. Andis, I27 Iowa 36, 102 N.W. 177 (I905); Campbell v. Rawdon, I8 N.Y. 4I2 (I858); Westcott v. Meeker, I44 Ia. 3 II, I22 N.W. 964 (Igog); Perrin v. Blake, I Hargrave, Law Tracts 503 (I 787 ).

${ }_{35}$ Robeson v. Duncan, 74 N.J. Eq. 745, 70 Atl. 685 (Igo8). 
two cases $^{36}$ in which the limitation was similar to that in the instant case the court distinguishes only the case cited by Kales although both cases turn on precisely the same point.

In passing, it might be noted that the following writers, neither cited nor distinguished by the court, are authority for the proposition that the Rule in Shelley's Case does apply to contingent remainders: I Coke, Inst. $378 \mathrm{~b}$ (I629); Fearne, Contingent Remainders 30, 34 (Ioth ed. I844); I Hayes, Conveyancing 544 (5th ed. I840); I Preston, Estates 267, 3 I9 (I820); 2 Washburn, Real Property I609 (6th ed. I902); Challis, Real Property I63 (3d ed. I9II); I Tiffany, Real Property 3 ro (6th ed, I903); 24 Halsbury, The Laws of England 229 (I9I2); Kales, Future Interests, $\$ 440$ (I920). ${ }^{37}$

A partial explanation of the court's mistake in believing the cases it cited were in point lies in the ambiguity of the term contingent remainder, an ambiguity which arises only when the term is discussed with reference to the Rule in Shelley's Case. The rule always requires a remainder to the indefinite successors of the ancestor as a necessary condition for its application. This remainder, apart from the rule, would always be contingent because the identity of the taker could not be ascertained until the ancestor's death. ${ }^{38}$ However, since the rule identifies the ancestor as the taker of the remainder, the remainder becomes vested. Hence, in this sense there is always "a struggle between the rule and the contingent remainder." 39 The contingent remainder involved in the principal case was utterly different. The contingency was an event which might or might not happen. Even when the ancestor was identified as the taker, he could take only a contingent interest pending the happening of the event. Further, since every case to which the rule could possibly apply would neces-

${ }^{36}$ Boon v. Boon, 348 IIl. I20, I80 N.E. 792 (r932); Hanes v. Central Illinois Utilities Co., 262 Ill. 86 , тo4 N.E. $5_{5} 6$ ( $19 \mathrm{I}_{4}$ ).

${ }_{37}$ Probably in no other field is the authority of writers so respected as in the field of real property law. However, what cases there are also seem opposed to the position of the Illinois court. See 48 Harv. L. Rev. II62, I212 (I935); 33 Mich. L. Rev. Ir12 (I935). The remainder "to the heirs" may be contingent in one of four ways: ( $x$ ) contingent upon the ancestor's having no children. Stewart v. Kenower, 7 W. \& S. (Pa.) 288 (I844); Eby v. Shank, $x 96$ Pa. 426, 46 Atl. 495 (I900); Loring v. Eliot, I6 Gray (Mass.) 568 (1860). The contingency in the principal case is of this nature; (2) contingent upon the ancestor's predeceasing or surviving a given person. McNeal v. Sherwood, 24 R.I. 3I4, 53 Atl. 43 (IgO2); (3) contingent upon the ancestor's not exercising a power of appointment, either testamentary or inter-vivos. Woodbridge $\mathrm{v}$. Jarrard, Ior N.J. Eq. 439, I38 Atl. 536 (I927); Cowing v. Dodge, I9 R.I. 605, 25 Atl. 309 (I896); (4) contingent upon the ancestor's having heirs. Williams v. Holly, 4 N.C. 266 ( $(18$ I5). It is suggested that these last two types of remainders do not involve genuine contingencies; the former does not because the grantee inevitably gets a fee simple; the last does not because the limitation does no more than state explicitly what is the intention of the grantor in every conveyance to "the ancestor, remainder to his heirs."

${ }^{38}$ Fearne, Contingent Remainders 8 (Ioth ed. 1844 ). It is within Mr. Fearne's class of contingent remainders.

${ }^{39}$ See Campbell v, Rawdon, I8 N.Y. 4I2, 420 ( 1858$)$. 
sarily involve a contingent remainder of the first sort, any court which held that the rule did not apply to contingent remainders in this first sense would have completely abolished the rule..$^{\circ}$

Another explanation of the court's difficulties lies in its belief that the doctrine of merger is a necessary adjunct to the application of the rule. ${ }^{41}$ According to the court, "the effect of the Rule in Shelley's Case when it applies 'is to vest the fee in the ancestor instantly and instantly to merge it with the freehold estate. If it does not apply in this manner it cannot apply at all." " $4^{2}$ Given this premise, the conclusion that the rule does not apply to contingent remainders follows inexorably since the contingent remainder could not merge with the preceding freehold. However, the authorities are united on the position that while merger generally does follow as a consequence of the rule, it is by no means necessary that merger be possible before the rule be applied. 43 The court's use of authority on this point is remarkably faulty. 44

A critical analysis of precedent might have led the court to the same result. First, there do not seem to be any Illinois cases in point one way or the other. There remains then the overwhelming array of textbook writers. ${ }^{45}$ But Messrs. Challis ${ }^{4}$ and Tiffany ${ }^{47}$ read Messrs. Preston and Fearne; Mr. Preston ${ }^{4}$ read Mr. Fearne; and Mr. Fearne ${ }^{49}$ read Coke. It is in a note by Coke that a case

${ }^{40}$ If when it is said that the rule does not apply to contingent remainders, the remainder "to the heirs," is regarded as a contingent remainder, the statement is tantamount to saying the rule never applies since the rule cannot apply unless there is a remainder to the heirs.

${ }_{4}$ The present court would seem to have fulfilled a prophecy made by Kales in his work on future interests written fifteen years before: "The correct operation of the Rule in Shelley's Case has, it is believed, never been distinctly noted by our Supreme Court. . . ." Its apparent belief, as shown by its ". . . handling of the usual cases of a gift to A for life, with remainder to A's heirs, is that the rule operates to give A a fee simple directly." Kales, Future Interests 504 (I920).

42 Gehlbach v. Briegel, 359 Ill. 316, x94 N.E. 59 I (1934).

43 I Hayes, Conveyancing 545 ( 5 th ed. 1844).

44 The next sentence of the opinion after the passage quoted above is a paraphrase of Hayes' general statement of the rule for which Hayes is cited by the court. The context however makes it reasonable to assume that the citation to Hayes is not in direct conflict with the discussion of merger. But one page later in his work Hayes emphatically and clearly distinguishes merger from the rule. Furthermore, two pages after the passage cited by the court Hayes explicitly states that the rule does apply to contingent remainders, the solution of the ultimate issue in the case for which the court at this stage of its opinion was merely preparing the ground. Thus, the court would seem to have exercised a nice sense of discrimination about those points of law in connection with the rule on which Mr. Hayes is an authority and those points on which he is not an authority.

45 Supra page I34.

${ }^{6}$ Challis, Real Property 163 , note (3d ed. Sweet rgrr).

${ }^{47}$ I Tiffany, Real Property 3 ro note, (6th ed. I903).

${ }^{4}$ Preston is avowedly merely a commentary on Fearne. See Introduction, I Preston, Estates (Ist ed. 1820).

49 I Fearne, Contingent Remainders 30 (xoth ed. I844). 
is put involving a contingent remainder and the suggestion is made that the rule applies..$^{\circ}$ Thus, it might have been argued that an apparently compelling array of authority is reducible to a three hundred year old footnote on a hypothetical case, which in itself might not compel a modern court to defeat the grantor's intent:

Another argument apart from precedent is possible. It should be noted that the remainder in the principal case is contingent upon an event necessarily involving the ancestor's death. Hence, since the ancestor could not possibly enjoy such a remainder as vested during his life, the utility of giving him the interest is dubious. ${ }^{5 x}$

As a matter of policy it cannot be denied that the court, despite the means it chose, has made a decision in harmony with modern trends. It has in a small measure narrowed the scope of the rule, and no inroad upon it is without merit. It has been strongly contended since the time of Mansfield ${ }^{52}$ that the rule has outlived its usefulness and its abolition in several states has been universally received as a worthy reform of the law.s3 Prof. Ernst Freund presented a draft of a proposed bill to the Illinois legislature at its sessions in 1907 and 1908.54 The bill did not become law. However, it is suggested that it is more fitting for the Assembly of Illinois intentionally to abolish the rule than for the Supreme Court to run the risk of accidentally doing so.

50 I Coke, Inst. $378 \mathrm{~b}$. The case was: "to A and B so long as they both live, then to the heirs of the one that died first."

${ }^{5 I}$ This argument would distinguish the case put by Hayes, the one authority who did not rely on Coke's note in this matter, from the principal case. Since the case put by Coke involved a remainder that could not vest during the life of the ancestor, it must be admitted that this argument is, as Mr. Fearne says, "directly contradicted by the authority of Lord Coke."

${ }_{52}$ During the heated disputes about Perrin v. Blake, Lord Mansfield was regarded as the leading opponent of the rule.

${ }^{53}$ See 45 Harv. L. Rev. 57I, 573 (1934) for list of thirty-three jurisdictions which have enacted statutes designed to abolish the rule. It has also been abrogated in England. Law of Property Act (I925) c. $20 \S$ I3I.

54 The following is the text of the bill:

Where any grant or devise hereafter taking effect of any property shall limit an estate for life or of freehold to any person and an estate in remainder to the heirs (or the heirs of any particular description) of such person, such person shall not be deemed to take an estate of inheritance, and the persons who, upon the taking effect of such remainder in possession, shall be the heirs (or the heirs of the class described as the same may be) of such person, shall take by virtue of the remainder so limited to them: it being the intent of this provision to abrogate the rule of law commonly known as the Rule in Shelley's Case. (See 4 Kales, Cases on Property, Future Interests 144 (xgI8).) 